\title{
On the durability of Burkea africana heartwood: evidence of biocidal and hydrophobic properties responsible for durability
}

\author{
Béli Neya, Mohamed HaKKou, Mathieu PÉTRISSANS, Philippe GÉRARdiN* \\ Laboratoire d'Études et de Recherches sur le Matériau Bois, UMR INRA 1093, Faculté des Sciences et Techniques. \\ Université Henri Poincaré, Nancy 1, Bld des Aiguillettes, BP 239, 54506 Vandœuvre-lès-Nancy Cedex, France
}

(Received 19 September 2002; accepted 5 March 2003)

\begin{abstract}
Analysis of the extracts contained in Burkea africana heartwood is studied with the aim of better understanding the reasons of the exceptional durability of this type of wood. The results obtained show that in spite of the fungicidal and termiticidal properties of certain products contained in the extracts, these properties do not allow to explain entirely the reasons of the durability. The strongly hydrophobic character of wood as its high dimensional stability would be also significant factors of its resistance. Analysis of the products present in the diethylether extracts indicates the presence of fats, waxes and squalene which could be the reason of the preceding results.
\end{abstract}

Burkea africana / extract / durability / dimensional stability / wettability

Résumé - À propos de la durabilité du bois de cœur de Burkea africana. L'analyse des matières extractibles contenues dans le Burkea africana est étudiée dans le but de mieux comprendre les raisons de la durabilité exceptionnelle de ce type de bois. Les résultats obtenus montrent que malgré les propriétés fongicides et termiticides de certains produits contenus dans les extraits, ces dernières ne permettent pas d'expliquer entièrement à elles seules les raisons de la durabilité. Le caractère hydrophobe du bois ainsi que sa forte stabilité dimensionnelle seraient également des facteurs importants de sa résistance. L'analyse des produits présents dans les extraits éthérés indique la présence de graisses, de cires et de squalène pouvant être à la base des résultats précédents.

Burkea africana / extrait / durabilité / stabilité dimensionnelle / mouillabilité

\section{INTRODUCTION}

Burkea africana Hook, also known under the common name of Mgando or Mkarati, is a tree distributed in dry savana forests throughout tropical Africa belonging to the family of Leguminosae. Its wood is hard and heavy particularly useful for constructional work such as bridges, sleepers, fences or for toolhandles. The heartwood is dark brown or reddish brown and described to be very resistant to fungi [1-3]. However, in spite of its exceptional decay resistance, no studies had been reported on the reasons of its natural durability and justify the studies on the nature and on the influence of extractives on durability of Burkea africana heartwood. Indeed, conventional preservation methods involve the impregnation of broadly active biocides into the wood to prevent fungal decay and insect attack [4]. However, in spite of their positive contribution for the forest products industry, wood preservation is coming under increasing scrutiny due to its negative influence on the environment justifying the development of new wood preservation systems [5] or development of new plantations with naturally durable species [6].

\section{MATERIALS AND METHODS}

Burkea africana heartwood was collected in a natural forest located in Leo in south of Burkina Faso. Solvents used for extraction were distilled before use excepted toluene purchased from Merck at a $99.8 \%$ purity which was used without further purification.

\subsection{Determination of the amount of extractives}

Heartwood was ground to fine sawdust powder, passed through a 115 mesh sieve and dried at $80^{\circ} \mathrm{C}$ before extraction with different solvents in a Soxhlet extractor. The temperature of $80{ }^{\circ} \mathrm{C}$ was chosen

\footnotetext{
* Corresponding author: Philippe.Gerardin@lermab.uhp-nancy.fr
} 
instead of the normalised $103{ }^{\circ} \mathrm{C}$ in order to avoid the possible degradation of some of the extracts. About $50 \mathrm{~g}$ of wood powder was extracted with $150 \mathrm{~mL}$ of toluene/ethanol mixture (2/1, v/v), diethylether or acetone for $16 \mathrm{~h}$ at the rate of 8-12 cycles per $\mathrm{h}$. After extraction the solvent was evaporated under reduced pressure and the residue dried over $\mathrm{P}_{2} \mathrm{O}_{5}$ in a dessicator before weighing.

\subsection{Decay resistance}

\subsubsection{Micro-organisms}

One white rot, Coriolus versicolor (CV) (Strain FPRL 28), and three brown rots Poria placenta (PP) (Strain FPRL 280), Gloeophyllum trabeum (GT) (Strain BAM Ebw 109) and Coniophora puteana (CP) (Strain BAM Ebw 15) were used throughout this study.

\subsubsection{Growth inhibition}

Mycelium was grown in $9 \mathrm{~cm}$ Petri dishes filled with $20 \mathrm{~mL}$ of maltagar medium prepared by solubilizing 15 grams of malt and 15 grams of agar in $1 \mathrm{~L}$ of distilled water containing different concentrations of extract (10, 100 and $1000 \mathrm{ppm})$. Introduction of the extracts was carried out after medium sterilization $\left(20 \mathrm{~min}, 120^{\circ} \mathrm{C}, 1 \mathrm{bar}\right)$ by addition of the necessary quantity of extract solubilized in acetone. Plates were inoculated by placing a $10 \mathrm{~mm}$ diameter plug, cut from the edge of a starting colony growing on malt-agar medium in the center of each plate. The cultures were kept 15 days in a growth chamber at $20^{\circ} \mathrm{C}$ at room humidity. Growth was evaluated every 2 or 3 days by measuring the diameter of the colony estimated from the mean of two perpendicular diameters and expressed as a percentage of the room available for growth, i.e. the diameter of the dish. Growth inhibition was calculated according to the formula:

$$
\text { Growth inhibition }(\%)=100 \times\left(1-\frac{\mathrm{d}_{1}}{\mathrm{~d}_{0}}\right) \text {, }
$$

where $d_{0}$ is the diameter of the control culture and $d_{1}$ the diameter of the culture in the presence of extracts. Experiments where stopped when the diameter of the control culture reached $9 \mathrm{~cm}$. All experiments are repeated three times. Controls realized with or without acetone show no difference concerning mycelium development.

\subsubsection{Decay test on blocks}

Dried blocks of Burkea africana $(5 \times 2.5 \times 1.5 \mathrm{~cm}$ in longitudinal, radial and tangential directions) were used for natural durability evaluation. Influence of extractives on durability was evaluated after extraction with toluene/ethanol mixture $(2 / 1, v / v)$, diethyl ether or acetone in a Soxhlet extractor for $16 \mathrm{~h}$. All blocks were dried at $80{ }^{\circ} \mathrm{C}$ until stabilization of their mass and weighed before exposition to fungi. Sterile culture medium $(150 \mathrm{~mL})$ prepared from malt $(15 \mathrm{~g})$ and agar $(15 \mathrm{~g})$ in distilled water $(1 \mathrm{~L})$ was placed in $1 \mathrm{~L}$ culture bottle, inoculated with Coriolus versicolor and incubated at $20{ }^{\circ} \mathrm{C}$ and $70 \%$ $\mathrm{RH}$ to allow colonization of the medium by the mycelium. Extracted or unextracted U.V. sterilized blocks (4 replicates) were placed in separated bottles and exposed to fungus for 16 weeks to evaluate influence of extractives on durability. After this period, mycelium was removed and blocks were weighed $\left(\mathrm{m}_{1}\right)$. Blocks were then dried at $80{ }^{\circ} \mathrm{C}$ until stabilization of their mass and weighed $\left(\mathrm{m}_{2}\right)$. Weight loss (WL) was expressed as a percentage of the initial ovendried weight of the sample according to the formula:

$$
\mathrm{WL} \%=\left(\left(\mathrm{m}_{0}-\mathrm{m}_{2}\right) / \mathrm{m}_{0}\right) \times 100,
$$

where $\mathrm{m}_{0}$ is the dried initial weight of the block and $\mathrm{m}_{2}$ the dried weight after exposition to Coriolus versicolor. Beech blocks (Fagus
Table I. Classification of natural durability of wood towards termites according to EN 117 standard.

\begin{tabular}{lc}
\hline Block aspect after test & Classification \\
\hline No attack & 0 \\
Attempt of attack & 1 \\
Weakly attacked & 2 \\
Moderately attacked & 3 \\
Strongly attacked & 4 \\
\hline
\end{tabular}

sylvatica) were used as controls and treated as described above. Wood humidity after exposition to fungi was calculated according to the formula:

$$
\text { Wood humidity } \%=\left(\left(\mathrm{m}_{1}-\mathrm{m}_{2}\right) / \mathrm{m}_{1}\right) \times 100 \text {, }
$$

where $\mathrm{m}_{1}$ is the wet weight of the block after exposition to Coriolus versicolor and $\mathrm{m}_{2}$ the dried weight of the block after exposition to Coriolus versicolor.

\subsection{Termites resistance}

Wood blocks $(5 \times 2.5 \times 1.5 \mathrm{~cm}$ in longitudinal, radial and tangential directions) were used for termite resistance tests using Reticulitermes santonensis de Feytaud. Pine blocks were used as controls. Three blocks extracted as above or not were placed separately with one control in a flask on Fontainebleau sand humidified with distilled water ( 1 volume for 4 volumes of sand). 256 termites ( 250 workers, 3 soldiers and 3 nymphs) were placed in each flask. After eight weeks, wood samples are classified from 0 to 4 according to the importance of the attack [7] (Tab. I)

\subsection{Wettability}

Wood wettability was measured by the Wilhelmy method according to a reported procedure [8-9]. Wood samples used for advancing contact angle $(\theta$ a) measurement were prealably subject to Soxhlet extraction with different solvents to evaluate the influence of extractives. Wood samples dimensions used for $\theta$ a determination are $20 \times$ $10 \times 1 \mathrm{~mm}$ in tangential, radial and longitudinal directions respectively. The measuring unit (tensiometer, processor K12 Krüss society) consists of a force measuring system (precision $0.02 \mathrm{mN} \mathrm{m}^{-1}$ ), a plateform drive system to raise and lower the sample automatically and determine its position and immersion depth during a test cycle. Measurements were performed at room condition $\left(20^{\circ} \mathrm{C}\right.$ and about $50-60 \%$ relative humidity). The wood sample was immersed in water along the radial direction. The velocity of immersion was $6 \mathrm{~mm} \mathrm{~m}^{-1}$.

\subsection{Dimensional stability}

Influence of extractives on dimensional stability was estimated using Anti-Swelling-Efficiency (ASE) measurements. ASE was determined by measuring the increase in volume of extracted and unextracted Burkea africana blocks. Blocks were immersed in distilled water and placed inside a dessicator. A vacuum of 30 mbar was realized during $30 \mathrm{~min}$ before restoration of atmospheric pressure. Five water soaking cycles were thus applied (changing the water every day) before determination of the water-saturated volume. Blocks were 
Table II. Quantity of extractives.

\begin{tabular}{lcc}
\hline Solvent & \multicolumn{2}{c}{ Yield (\%) } \\
\hline Diethylether & $3.0^{\mathrm{a}}$ & $3.1^{\mathrm{b}}$ \\
Acetone & $14.6^{\mathrm{a}}$ & $14.8^{\mathrm{b}}$ \\
Toluene/ethanol & $17.5^{\mathrm{a}}$ & $18.1^{\mathrm{b}}$ \\
\hline
\end{tabular}

${ }^{a}$ According to extract weight; ${ }^{b}$ according to sawdust weight.

then removed from water, wiped, and measured. The volumetric swelling coefficients were calculated according to the formula [10]:

$$
\mathrm{S}(\%)=\left(\left(\mathrm{V}_{\mathrm{w}}-\mathrm{V}_{\mathrm{d}}\right) / \mathrm{V}_{\mathrm{d}}\right) \times 100 \text {, }
$$

where $\mathrm{V}_{\mathrm{w}}=$ volume of water saturated wood and $\mathrm{V}_{\mathrm{d}}=$ volume of wood dried at $80{ }^{\circ} \mathrm{C}$.

The percentage of swelling was calculated from the wet and ovendried volumes of unextracted and extracted blocks according to:

$$
\operatorname{ASE}(\%)=((\mathrm{Se}-\mathrm{Su}) / \mathrm{Se}) \times 100,
$$

where $\mathrm{Se}=$ volumetric swelling coefficient of extracted samples and $\mathrm{Su}=$ volumetric swellling coefficient of unextracted samples.

\subsection{Chemical analysis}

FTIR spectra were recorded as film between $\mathrm{NaCl}$ plates or $\mathrm{KBr}$ disks on a Perkin Elmer FTIR spectrometer Spectrum 2000. ${ }^{1} \mathrm{H}$ NMR spectra were recorded on a Bruker AM 400 spectrometer. Extracts were analyzed by combined gas chromatography-mass spectrometry (GS-MS) on a Fisons MD 800 at an ionizing potential of $70 \mathrm{e} . \mathrm{V}$. and maintaining a source temperature of $200{ }^{\circ} \mathrm{C}$. Products were separated on a DB-5-fused silica capillary column (length: $15 \mathrm{~m}$; diameter: $0.25 \mathrm{~mm}, \mathrm{~J} \& \mathrm{~W}$ Scientific). The temperature program started at $50{ }^{\circ} \mathrm{C}$ and held for $2 \mathrm{~min}$, then raised at $10{ }^{\circ} \mathrm{C} / \mathrm{min}$ to $250{ }^{\circ} \mathrm{C}$ and held at $250{ }^{\circ} \mathrm{C}$ for $30 \mathrm{~min}$. Helium was used as the carrier gas. Identification of products was performed using NIST library and reference samples used to confirm attribution.

\section{RESULTS AND DISCUSSIONS}

The quantities of extractives contained in the wood of Burkea africana are reported in Table II. The two methods used to quantify these latter, namely the direct method based on the weight of the extracts after evaporation of the solvent and the indirect method based on the mass loss of sawdust, give very near results indicating that practically no products are lost during vacuum evaporation. The quantity of extracts increases with the solvent polarity and is in agreement with the strong contents of extractives often observed in some tropical wood [11]. Figures 1, 2 and 3 report effects of the different extracts on the growth of brown rot and white rot fungi. In all cases, a significant effect was observed on the growth of the mycelium at 100 and $1000 \mathrm{ppm}$ of the different extracts tested. The acetone and toluene/ethanol extracts lead to similar results on the four fungi tested indicating probably the presence of the same molecules. The diethylether extract has a behavior a little different from the two precedents and seems particularly active on

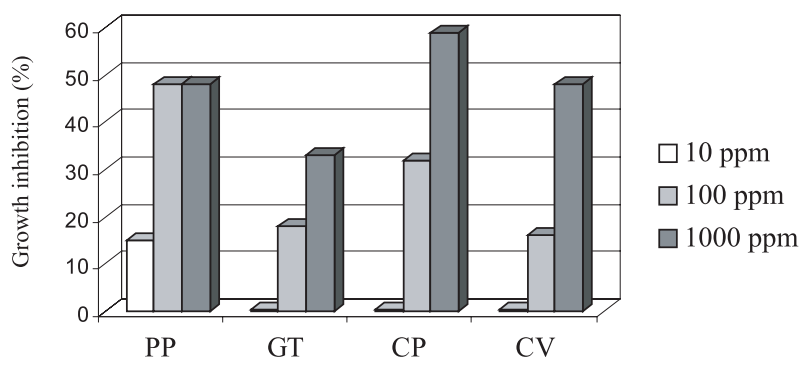

Figure 1. Effect of toluene/ethanol extracts on growth of wood rotting fungi: Poria placenta (PP), Gloeophyllum trabeum (GT), Coniophora puteana $(\mathrm{CP})$, Coriolus versicolor $(\mathrm{CV})$.

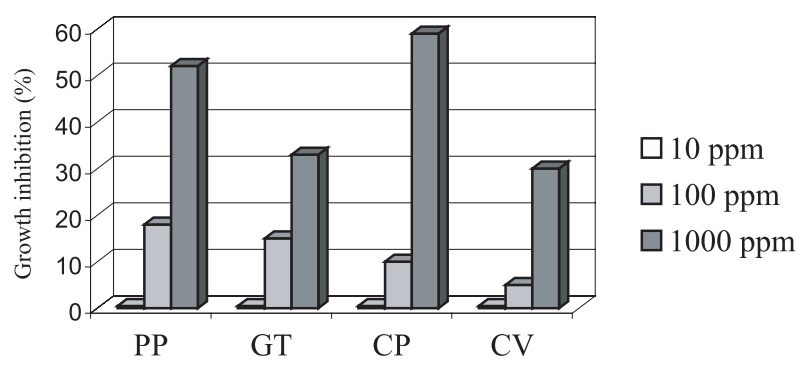

Figure 2. Effect of acetone extracts on growth of wood rotting fungi: Poria placenta (PP), Gloeophyllum trabeum (GT), Coniophora puteana $(\mathrm{CP})$, Coriolus versicolor $(\mathrm{CV})$.

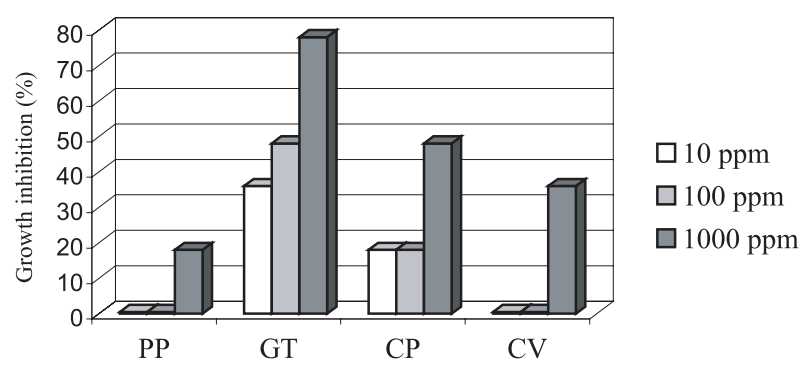

Figure 3. Effect of diethylether extracts on growth of wood rotting fungi: Poria placenta (PP), Gloeophyllum trabeum (GT), Coniophora puteana $(\mathrm{CP})$, Coriolus versicolor $(\mathrm{CV})$.

the development of Gloeophyllum trabeum. No difference is observed between white rot and brown rot fungi.

To confirm the influence of extractives on the natural durability of Burkea africana heartwood, we studied the behavior of blocks extracted or not exposed to Coriolus versicolor during 16 weeks. The results are reported in Table III. Independently of the nature of the extraction, weight losses observed on Burkea africana blocks are weak, while beech blocks are strongly degraded. These results suggest that the durability of Burkea africana heartwood is not only due to the presence of extractives but depends also of other factors. Among these, the wood hydrophobicity could be an important reason of its exceptional durability. Indeed, wood humidity measured after 16 weeks is lower than $30 \%$, which could create unfavourable conditions approaching the $22 \%$ reported in the literature as 
Table III. Weight losses of tested blocks.

\begin{tabular}{lccc}
\hline Species & Extraction & Weight loss ${ }^{\text {a }}$ (\%) Wood humidity (\%) \\
\hline Burkea africana & Diethylether & 2.2 & 27 \\
Burkea africana & Acetone & 2.9 & 27.2 \\
Burkea africana & Toluene/ethanol & 1.2 & 25.8 \\
Burkea africana & None & 2.5 & 22.5 \\
Fagus sylvatica & None & 35.3 & 37.0 \\
\hline
\end{tabular}

${ }^{a}$ Average value on four replicates.

Table IV. Hydrophobic properties of tested blocks.

\begin{tabular}{lcccc}
\hline Species & Extraction & $\mathrm{S}(\%)^{\mathrm{a}}$ & ASE $(\%)^{\mathrm{b}}$ & $\theta_{\mathrm{a}}\left({ }^{\circ}\right)^{\mathrm{c}}$ \\
\hline Burkea africana & Diethylether & 11 & 44.3 & 28 \\
Burkea africana & Acetone & 6.6 & 8.3 & 77 \\
Burkea africana & Toluene/ethanol & 6.5 & 5.7 & 53 \\
Burkea africana & None & 6.1 & - & 62 \\
Fagus sylvatica & None & 19 & - & 0
\end{tabular}

${ }^{a}$ Swelling coefficient; ${ }^{\mathrm{b}}$ Anti Swelling Efficiency; ${ }^{\mathrm{c}}$ Advancing contact angle.

Table V. Resistance to termites.

\begin{tabular}{lcccc}
\hline \multirow{2}{*}{ Species } & Extraction & \multicolumn{3}{c}{ Results } \\
\cline { 3 - 5 } & & $\begin{array}{c}\text { Workers } \\
\text { surviving } \\
(\%)\end{array}$ & $\begin{array}{c}\text { Soldiers } \\
\text { or nymphs } \\
\text { surviving (\%) }\end{array}$ & Classification \\
\hline Burkea africana & Diethylether & 0 & 0 & 1 to 2 \\
Burkea africana & Acetone & 0 & 0 & 1 \\
Burkea africana & Toluene/ethanol & 1.6 & 0 & 1 \\
Burkea africana & None & 3.8 & 0 & 1 \\
Pinus sylvestris & None & 71.6 & 6.4 & 3 to 4 \\
\hline
\end{tabular}

being necessary to the good development of most wood rotting fungi $[12,13]$. Contact angle measurement confirms also the hydrophobic character of Burkea africana wood compared to beech wood (compare $62^{\circ}$ to $0^{\circ}$, Tab. IV). Influence of extractives on the $\theta \mathrm{a}$ value indicates that diethylether extracts are strongly hydrophobic and lead after extraction to a smaller contact angle, while toluene/ethanol and acetone extracts, which contain polar and apolar compounds, have a lesser effect on the contact angle value. Explanations of the limited effect of extractives on the ASE and $\theta$ a values is probably due to the difficulty to remove these latter one from solid wood as demonstrated by additional experiments performed on Burkea africana blocks (results not shown).

Hydrophobic compounds contained in diethylether extracts take an important part in the dimensional stability of Burkea africana wood, which was demonstrated by the high values of swelling coefficient and anti swelling efficiency measured. Results reported in Table V indicate also that Burkea africana heartwood is very durable toward termites.

Determination of the nature of the compounds contained in the different extracts were investigated by FTIR, ${ }^{1} \mathrm{H}$ NMR and GC-MS analysis. FTIR analysis are reported in Figure 4. FTIR spectrum of etheral extract indicates strong absorptions at 2920,2850 and $1730 \mathrm{~cm}^{-1}$ characteristic of $\mathrm{CH}$ and $\mathrm{C}=\mathrm{O}$ bonds present in fats and waxes. FTIR spectra of acetone and toluene/ ethanol extracts present additional absorptions at 3350, 1600, 1515 and $1450 \mathrm{~cm}^{-1}$ characteristic of $\mathrm{O}-\mathrm{H}$ and $\mathrm{C}=\mathrm{C}$ bonds corresponding to phenolic compounds which could be extracted due to the higher solvent polarity. ${ }^{1} \mathrm{H}$ NMR spectrum of etheral extract confirms the presence of waxes and fats (protons of alkyl chain between 0.9 and $1.5 \mathrm{ppm}$, protons attached to alpha oxygenated carbon between 3.5 and 4 ppm and ethylenic protons between 7 and $7.5 \mathrm{ppm}$ ). Peak at $11.5 \mathrm{ppm}$ indicates also the presence of carboxylic acid like fatty acids. ${ }^{1} \mathrm{H}$ NMR spectra of toluene/ethanol and acetone extracts are much more difficult to exploit due to the poor solubility of the products.

GC-MS analysis are reported in Figure 6. All chromatograms present the same typical peaks indicating that only a part of the extract corresponding to the more volatile compounds could be analyzed. Identification of the products using NIST library indicates the presence of squalene corresponding to the peak at $25 \mathrm{~min}$. Presence of this latter was confirmed after injection of a commercial sample of squalene which appears for the same retention time. ${ }^{1} \mathrm{H}$ NMR analysis of squalene allows also to identify the product in the crude etheral extract (peaks between 1.95-2.2 for protons attached to carbon in alpha position of unsaturated systems and 5.1-5.2 ppm for vinylic protons) (Fig. 5). Other peaks correspond to compounds bearing fatty alkyl chain but were more difficult to identify.

\section{CONCLUSION}

As it was reported in the literature [1-3], Burkea africana heartwood is very resistant to termites and fungal attacks. Different reasons allow to explain this exceptional durability. The first one concerns the presence of biocidal compounds in extractives, which are shown to inhibit mycelium growth of several brown rot and white rot fungi on malt agar medium. The second reason lies in the strong hydrophobic character of Burkea africana heartwood. Indeed, the high dimensionnal stability of Burkea africana characterized by low swelling coefficient compared to beech wood and its low wettabilitty diminish humidity uptake leading to low water content which create unfavorable conditions for the development of fungi.

These results suggest that dimensional stabilization treatments associated with environmentally acceptable biocidal compounds could be interesting alternatives to conventional wood preservation products involving broadly active biocides. Further studies are also necessary to identify the products responsible for the biocidal properties. 
a)

b)
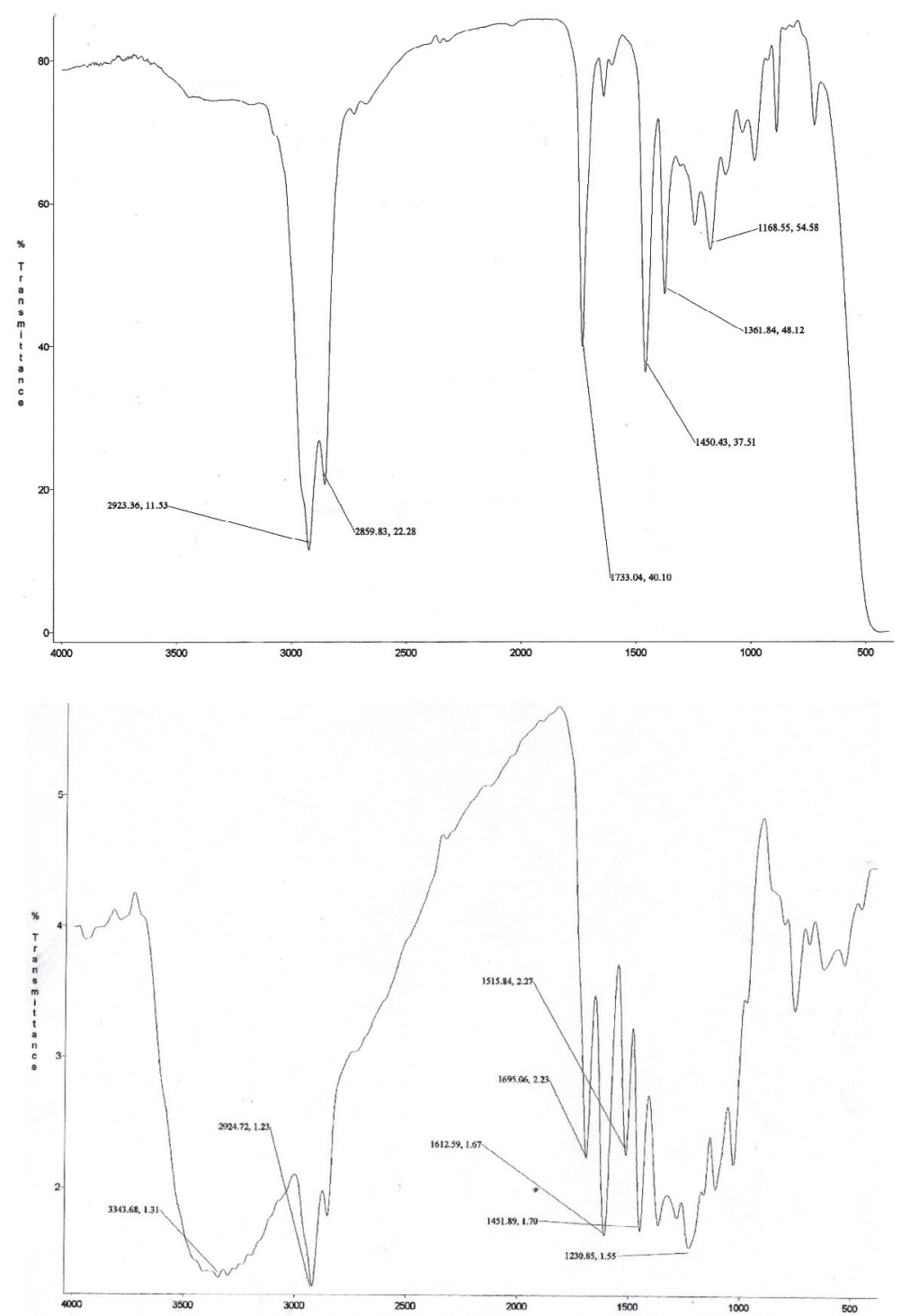

c)

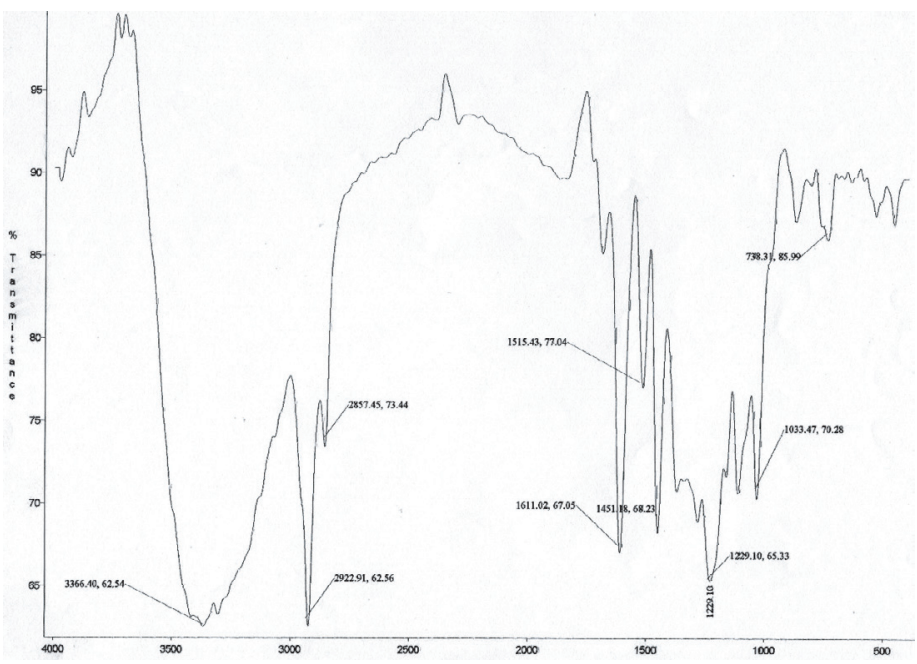

Figure 4. FTIR spectra of Burkea africana extracts : (a) diethylether extract, (b) acetone extract, (c) toluene/ethanol extract. 

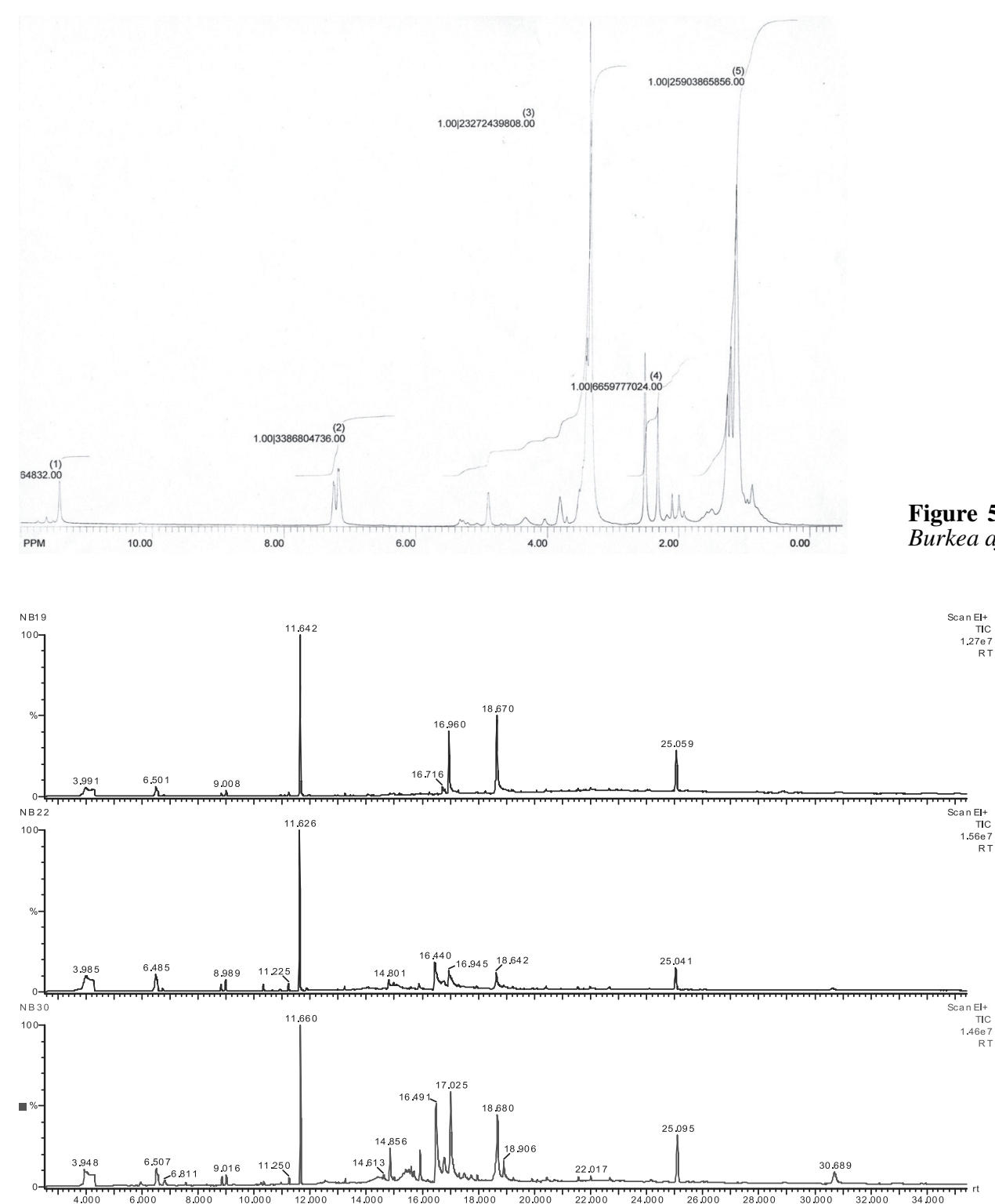

Figure 5. ${ }^{1} \mathrm{H}$ NMR spectra of etheral extract of Burkea africana.

Figure 6. GC-MS chromatograms of Burkea africana extracts: (a) diethylether extract, (b) acetone extract, (c) toluene/ethanol extract.

\section{REFERENCES}

[1] Aubréville A., Burkea africana, in: Flore Forestière SoudanoGuinéenne, Société d'Éditions Géographiques, Maritimes et Coloniales, Paris, 1950, pp. 244-246.

[2] Irvine F.R., Burkea africana, in: Woody Plants of Ghana, Oxford University Press, London, 1961, pp. 276-277.

[3] Dalziel J.M., Burkea Hook, in: The useful plants of West Tropical Africa (An appendix to the Flora of West Tropical Africa), Crown Agents for Oversea Governments and Administrations, London, 1937, p. 612.

[4] Barnes H.M., R.J. Murphy. Wood protection. The classics and the new age. For. Prod. J. 45 (1995) 16-23.

[5] Suttie E., Novel wood preservatives, Chem. Ind. 18(1997) 720-724.

[6] Brunetti M., L. De Capua E., Macchioni N., Monachello S., Natural durability, physical and mechanical properties of Atlas cedar ( $\mathrm{Ced}$ - rus atlantica Manetti) wood from southern Italy, Ann. For. Sci. 58 (2001) 607-613.

[7] EN 117, Determination of toxic values against Reticulitermes santonensis de Feytaud (laboratory method), 1990.

[8] Wålinder M., Johansson I., Measurement of wood wettability by the Wilhelmy method, Part 1, Holzforschung 55 (2001) 21-32.

[9] Wålinder M. Ström G., Measurement of wood wettability by the Wilhelmy method, Part 2, Holzforschung 55 (2001) 33-41.

[10] Stamm A.J., Wood and Cellulose Science, Ronald Press Co., New York, 1964

[11] Fengel D., Wegener G., Chemical analysis and composition of wood in Wood Chemistry, Ultrastructure, Reaction, Walter de Gruyter, Berlin, New York, 1984, pp. 26-65.

[12] Ridout B., Post-harvest changes and decay in Timber decay in buildings. E and FN Spon, London, 2000, pp. 23-36.

[13] Rayzal, M., Durabilité et préservation, in: Guide de la préservation du bois, CTBA, 1998, pp. 4-14. 